\title{
PERBANDINGAN KONSUMSI ENERGI ALGORITMA AES (256 BIT) DAN TWOFISH (256 BIT) PADA PONSEL BERBASIS ANDROID
}

\author{
${ }^{1}$ Serli Liling Allo \\ ${ }^{2}$ M. Subali \\ ${ }^{1}$ Teknik Elektro Politeknik Katolik Saint Paul, SerliLilingAllo@gmail.com \\ 2 Fakultas Teknologi dan Rekayasa Universitas Gunadarma, \\ subali@staff.gunadarma.ac.id
}

\begin{abstract}
ABSTRAK
Menjalankan aplikasi enkripsi/dekripsi pada ponsel akan diikuti oleh pemakaian $C P U$, memori, dan energi yang tersimpan dalam baterai sementara ketersediaan energi baterai terbatas, oleh karena itu cukup penting mengetahui berapa konsumsi energi dari algoritma enkripsi/dekripsi untuk menjadi salah satu bahan pertimbangan dalam pemilihan algoritma. Tujuan dari penelitian ini adalah untuk membandingkan konsumsi energi algoritma AES (256 bit) dan Twofish (256 bit) pada ponsel android. Untuk mencapai tujuan tersebut maka perlu diketahui arus, tegangan dan waktu enkripsi/dekripsi. Dalam penelitian ini arus dan tegangan diperoleh dari pengukuran langsung sedangkan waktu enkripsi/dekripsi dari algorithm benchmark pada program aplikasi SSE (Secret Space Encryptor). Konsumsi energi diperoleh dari perkalian antara arus, tegangan, dan waktu enkripsi/dekripsi. Dari hasil penelitian diperoleh konsumsi energi algoritma AES (256 bit) lebih besar dari algoritma Twofish (256 bit).

Kata kunci: AES (256 bit), konsumsi energi enkripsi/dekripsi, Twofish (256 bit)
\end{abstract}

\section{PENDAHULUAN}

Lembaga riset Gartner memprediksi tahun 2015 Android akan mengendalikan $48,8 \%$ OS (Operating System) di dunia. Dengan semakin maraknya pengguna smartphone maka pengiriman pesan instan melalui jaringan nirkabel juga semakin banyak digunakan. Namun pesan yang dikirim melalui jaringan nirkabel lebih mudah disadap oleh orang yang tidak berhak. Jika pesan yang dikirim tidak terlalu penting maka meskipun terjadi penyadapan pengirim/penerima tidak akan terlalu dirugikan, sebaliknya jika pesan berisi informasi penting atau rahasia maka keamanan dalam pertukaran informasi menjadi hal yang sangat penting.

Untuk menjamin kerahasiaan pesan meskipun berhasil disadap oleh penyerang (attacker) maka sebelum dikirim pesan dienkripsi terlebih dahulu sehingga menjadi pesan tersandikan yang sulit untuk dimengerti.

Menjalankan sebuah aplikasi pada ponsel dalam hal ini aplikasi enkripsi/dekripsi akan diikuti oleh konsumsi sumber daya CPU, memori, dan energi baterai, di sisi lain ketersediaan energi baterai terbatas. Dengan demikian konsumsi energi dari setiap algoritma adalah hal yang perlu diketahui agar dapat memilih algoritma dengan konsumsi energi lebih rendah dan keamanannya juga tinggi.

Penelitian ini bertujuan membandingkan pemakaian energi baterai jika menggunakan algoritma AES(256 bit) dan Twofish (256 bit) pada smartphone berbasis 
Android. Ada beberapa aplikasi enkripsi untuk ponsel android yang dapat diunduh di Google Play Store, yang digunakan dalam penelitian ini adalah SSE (Secret Space Encryption).

\section{TINJAUAN PUSTAKA}

Kekuatan dari sebuah algoritma enkripsi bergantung pada panjang kunci dan jumlah ronde, namun semakin besar ukuran kunci dan jumlah ronde maka konsumsi daya juga akan semakin besar (Chandramouli, dkk. 2006). Hubungan antara vulnerability dan konsumsi daya untuk jumlah ronde yang bervariasi dapat dilihat pada gambar berikut :

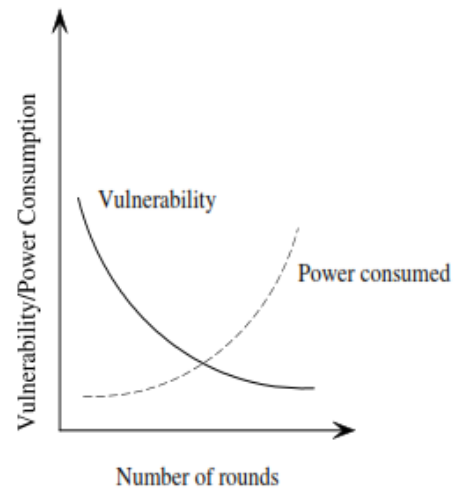

\section{Gambar 1. Keamanan vs konsumsi daya}

Sumber: Chandramouli, dkk. (2006)

Beberapa hasil penelitian yang berhubungan dengan konsumsi daya dan energi dari algoritma kriptografi dapat dilihat pada gambar-gambar berikut :

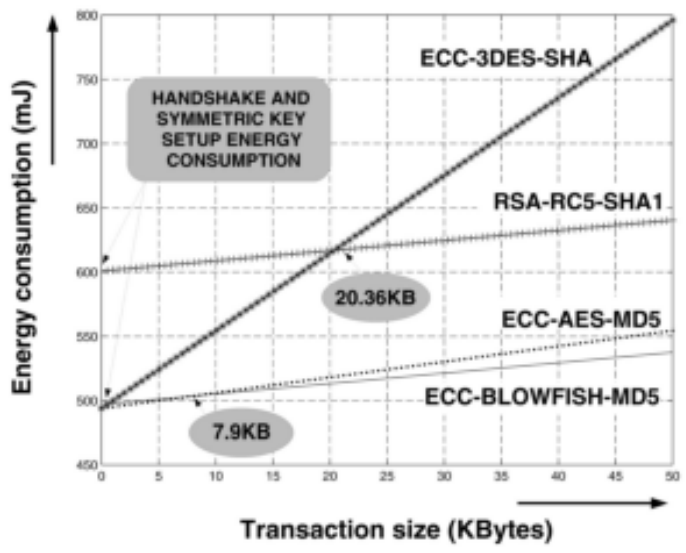

Gambar 2. Konsumsi energi selama SSL Handshake

Sumber: Potlapally, dkk. (2006) 


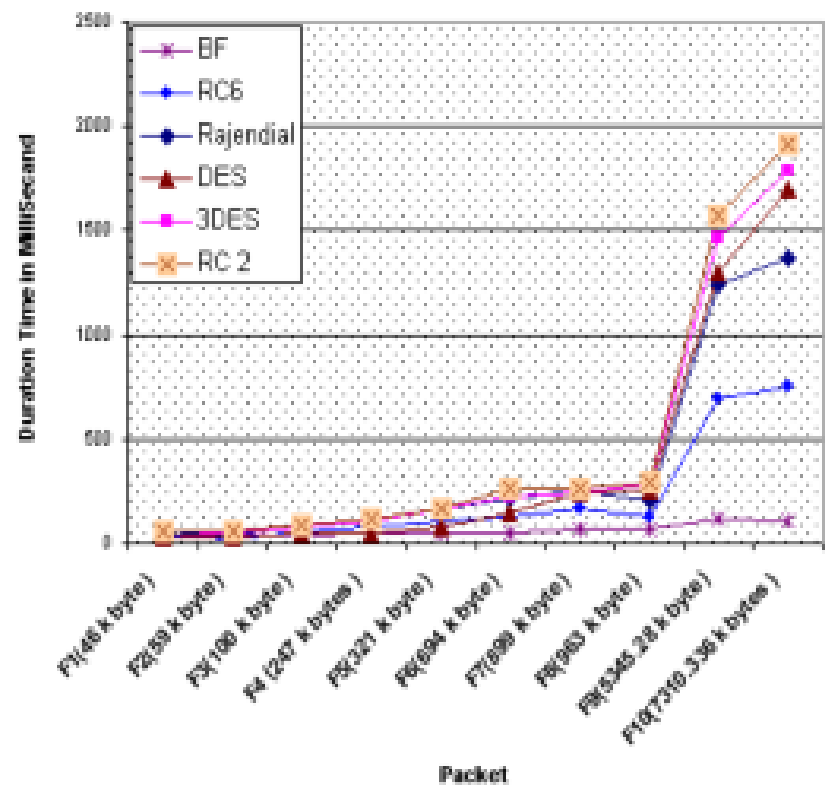

Gambar 3. Waktu enkripsi beberapa algoritma Sumber: Minaam, dkk. (2010)

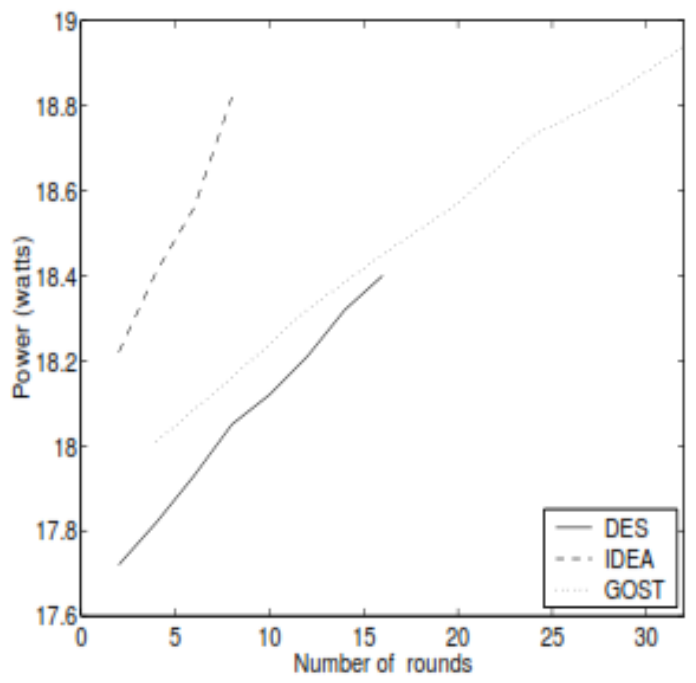

Gambar 4. Konsumsi daya vs jumlah ronde dari DES, IDEA, dan GOST Sumber: Chandramouli, dkk.( 2006) 


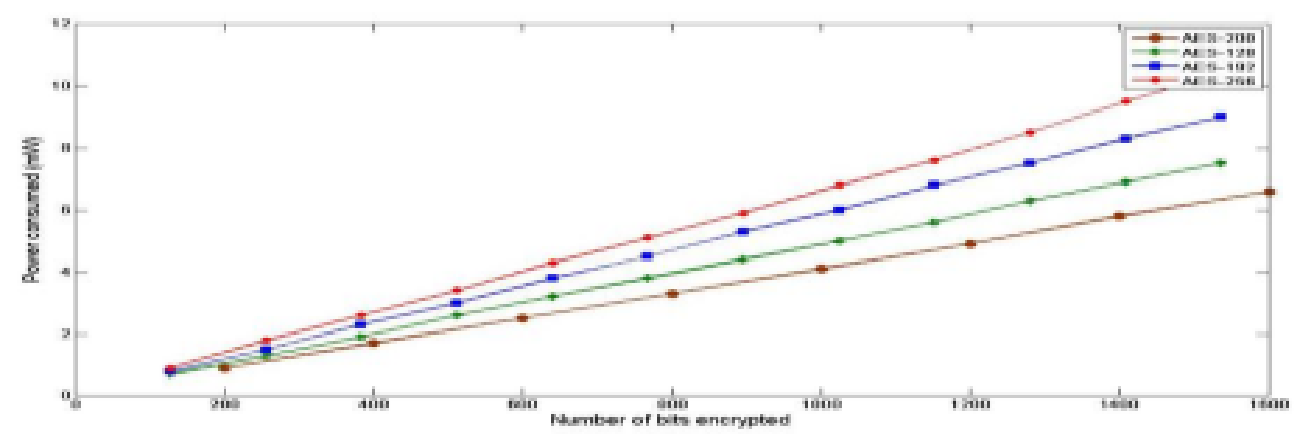

Gambar 5. Konsumsi daya vs jumlah bit yang dienkripsi AES untuk panjang kunci yang bervariasi

Sumber: Khatri, dkk. (2012)

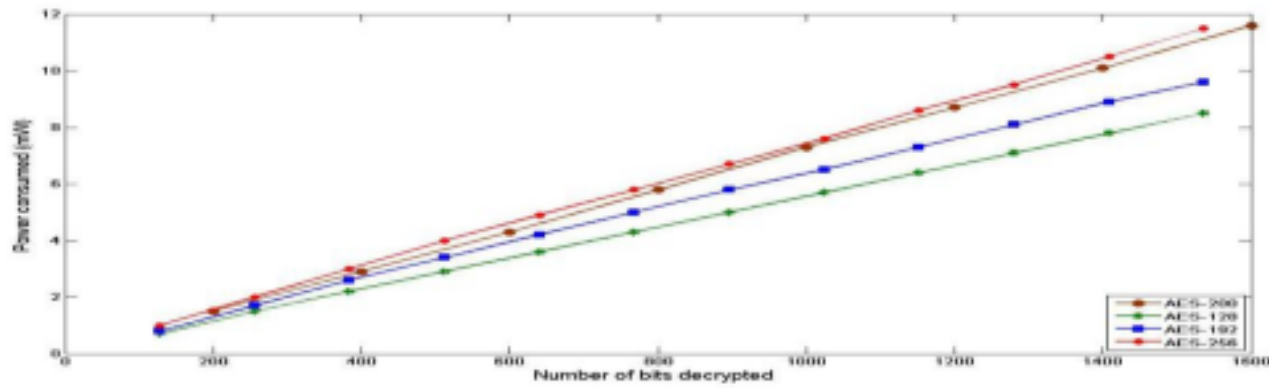

Gambar 6. Konsumsi daya vs jumlah bit yang dienkripsi AES untuk panjang kunci yang bervariasi

Sumber: Khatri, dkk. (2012)

Untuk memudahkan menghitung konsumsi energi dari sebuah software digunakan penyederhanaan dengan menggunakan rumus :

$\mathrm{E}=\mathrm{V}$. I . t

E adalah energi, $\mathrm{V}$ adalah tegangan supply, I adalah arus, dan t adalah waktu eksekusi program.

\section{METODE PENELITIAN}

Teknik pengumpulan data yang digunakan dalam penelitian ini ada dua yaitu pengumpulan data dengan cara mengumpulkan informasi-informasi dari berbagai sumber yang mendukung penelitian baik itu dari buku, jurnal ilmiah, makalah, prosiding maupun artikel dari internet yang mendukung penelitian ini (library research) dan pengumpulan data melalui eksperimen (experimental research) untuk mengetahui kecepatan enkripsi/dekripsi, tegangan, dan arus listrik yang dibutuhkan pada saat enkripsi/dekripsi menggunakan algoritma AES (256 bit) dan Twofish (256 bit) yang kemudian digunakan untuk menghitung besar konsumsi energi baterai.

Untuk mengetahui kecepatan enkripsi/dekripsi dari tiap algoritma maka digunakan alat dan bahan sebagai berikut : 
1. Samsung Galaxy Ace Duos (GT-S6802)

Spesifikasi ponsel ini adalah :

- Sistem operasi yang digunakan Androd 2.3 (Gingerbread)

- Prosesor $832 \mathrm{MHz}$

- RAM 512MB

- Kapasitas baterai $1300 \mathrm{mAh}$

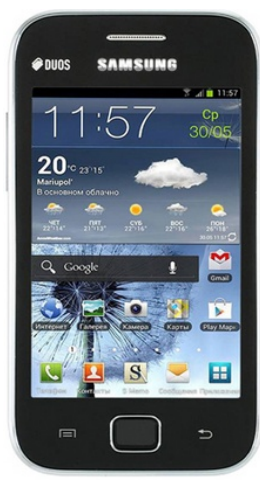

\section{Gambar 7 Samsung GT-S6802}

2. Program aplikasi SSE (Secret Space Encryption)

Program ini berfungsi untuk mengenkripsi dan mendekripsi pesan dan dapat menampilkan tolok ukur algoritma (benchmark algorithm) yang merupakan nilai estimasi kecepatan enkripsi/dekripsi dari algoritma yang digunakan. Dapat diunduh

dari Google Play Store atau dari http://www.paranoiaworks.mobi/ download/downloads.html. berikut :

Sedangkan untuk mengetahui tegangan dan arus listrik digunakan alat-alat sebagai

a. Catu daya (Power Supply)

Power supply digunakan untuk menghidupkan ponsel. Pada penelitian ini digunakan dua buah power supply, yaitu H\&K-1502DD (digital) dan H\&K 1501 T (analog).

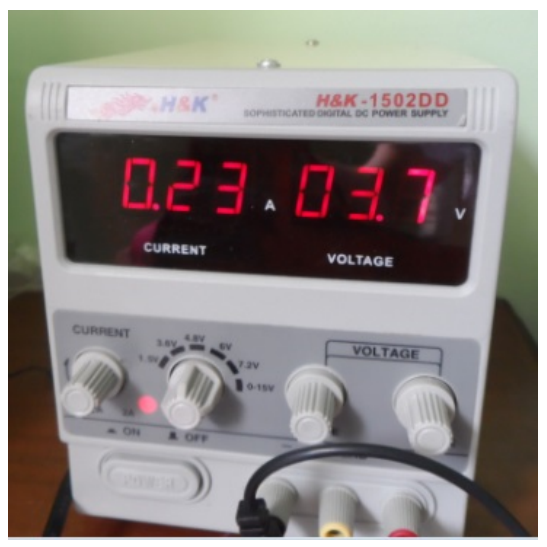

Gambar 8 Power Supply Digital H\&K-1502DD 


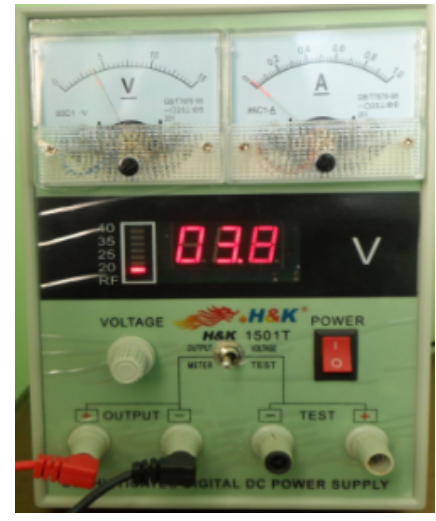

\section{Gambar 9 Power Supply Analog H\&K 1501T}

Alasan menggunakan dua buah power supply adalah:

- Untuk membandingkan hasil pengukuran masing-masing power supply sehingga diperoleh hasil yang lebih akurat.

b. Multimeter digital

Digunakan untuk mengukur tegangan output dari power supply untuk memastikan tegangan output tersebut sudah benar sebelum dihubungkan ke ponsel.



\section{Gambar 10 Multimeter Digital CD800a}

Langkah-langkah percobaan :

1. Catu daya diset pada tegangan $3.7 \mathrm{~V}$

2. Tegangan output catu daya diukur dengan multimeter untuk memastikan tegangan output sudah sesuai

3. Baterai ponsel dilepas kemudian positif dan negatif ponsel dihubungkan dengan positif dan negatif catu daya seperti pada gambar di bawah : 


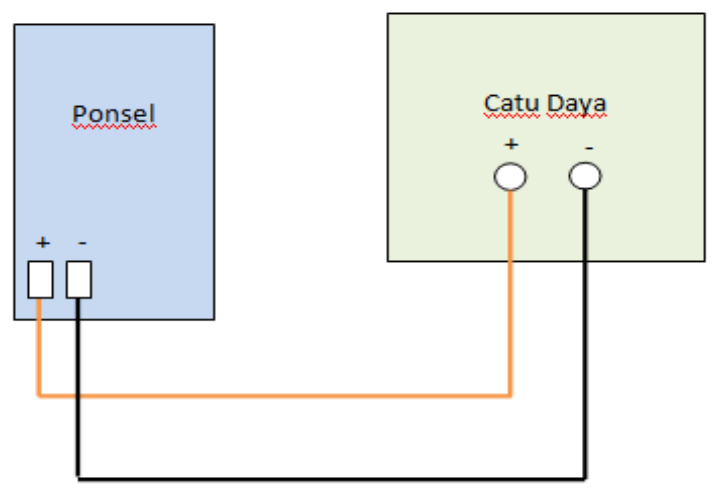

\section{Gambar 11 Skema rangkaian pengukuran arus dan tegangan}

4. Ponsel dinyalakan kemudian perubahan arus listrik yang ditampilkan pada catu daya diamati

5. Semua aplikasi yang berjalan di belakang layar dimatikan dan kecerahan layar diatur pada posisi paling minimum.

6. Aplikasi SSE dijalankan dan besar arus listrik pada saat idle dan pada saat proses enkripsi/dekripsi diukur.

Untuk menghitung konsumsi baterai maka digunakan teknik yang sama dengan penelitian yang dilakukan oleh A. Sinha dan A. P. Chandrakasan (2001) dalam penelitian mereka yang berjudul "Joule track - A web Based Tool for Software Energy Profiling," yang juga diikuti oleh D. S. A. Minaam, dkk. (2010) dalam penelitian yang berjudul "Evaluating the Effect of Symmetric Cryptography Algorithms on Power Consumption for Different Data Types," yaitu untuk memperoleh besarnya konsumsi energi maka digunakan rumus (1)

Dalam pengukuran arus digunakan teknik yang sama dengan teknik yang digunakan oleh R. Chandramouli, dkk. (2006) dalam penelitian yang berjudul "Battery Power-Aware Encryption", yaitu untuk menghilangkan pengaruh dari aplikasi yang berjalan di balik layar (background) maka pengukuran arus dilakukan pada saat tidak ada aplikasi lain yang sedang berjalan. Perbedaan antara arus ketika enkripsi/dekripsi dijalankan dengan arus idle diasumsikan sebagai arus untuk enkripsi/dekripsi.

\section{HASIL DAN PEMBAHASAN}

\section{Pengukuran kecepatan algoritma AES (256 bit) dan Twofish (256 bit)}

Dari beberapa percobaan diperoleh tolok ukur algoritma (algorithm benchmark), yang dapat dijadikan sebagai acuan untuk memperkirakan kecepatan enkripsi/dekripsi. 
Tabel 1.

Algorithm Benchmark untuk AES (256 bit)

\begin{tabular}{|c|c|c|c|c|}
\hline \multirow{2}{*}{$\begin{array}{c}\text { Percobaan } \\
\text { ke- }\end{array}$} & \multicolumn{2}{|c|}{ A = 15.360 byte } & \multicolumn{2}{c|}{ B = 262.144 byte } \\
\cline { 2 - 5 } & $\begin{array}{c}\text { Enc. A } \\
\text { (MB/s) }\end{array}$ & $\begin{array}{c}\text { Dec. A } \\
\text { (MB/s) }\end{array}$ & $\begin{array}{c}\text { Enc. B } \\
\text { (MB/s) }\end{array}$ & $\begin{array}{c}\text { Dec. B } \\
\text { (MB/s) }\end{array}$ \\
\hline 1 & 2,65 & 2,70 & 2,92 & 3,27 \\
\hline 2 & 2,66 & 2,56 & 2,93 & 3,49 \\
\hline 3 & 2,67 & 2,54 & 2,89 & 3,43 \\
\hline 4 & 2,45 & 2,62 & 2,82 & 3,49 \\
\hline 5 & 2,67 & 2,54 & 2,89 & 3,43 \\
\hline 6 & 2,67 & 2,71 & 2,92 & 3,31 \\
\hline 7 & 2,69 & 2.72 & 2.98 & 3,56 \\
\hline 8 & 2,65 & 2,72 & 3,23 & 3,58 \\
\hline 9 & 2,68 & 2,72 & 2,99 & 3,56 \\
\hline 10 & 2,71 & 2,71 & 2,83 & 3,50 \\
\hline $\begin{array}{l}\text { Rata-Rata } \\
\text { Hitung }\end{array}$ & $\bar{X}_{A A}=\mathbf{2 , 6 5 0}$ & $\bar{Y}_{A A}=\mathbf{2 , 6 5 4}$ & $\bar{X}_{B A}=\mathbf{2 , 9 4 0}$ & $\bar{Y}_{B A}=\mathbf{3 , 4 6 2}$ \\
\hline
\end{tabular}

$\bar{X}_{A A}=$ rata-rata kecepatan enkripsi A dengan algoritma AES (256 bit)

$\bar{Y}_{A A}=$ rata-rata kecepatan dekripsi A dengan algoritma AES (256 bit)

$\bar{X}_{B A}=$ rata-rata kecepatan enkripsi B dengan algoritma AES (256 bit)

$\bar{Y}_{B A}=$ rata-rata kecepatan dekripsi B dengan algoritma AES (256 bit)

Tabel 2.

Algorithm Benchmark untuk Twofish (256 bit)

\begin{tabular}{|c|c|c|c|c|}
\hline \multirow{2}{*}{$\begin{array}{c}\text { Percobaan } \\
\text { ke- }\end{array}$} & \multicolumn{2}{|c|}{ A = 15.360 byte } & \multicolumn{2}{c|}{ B = 262.144 byte } \\
\cline { 2 - 5 } & $\begin{array}{c}\text { Enc. A } \\
(\mathbf{M B} / \mathbf{s})\end{array}$ & $\begin{array}{c}\text { Dec. A } \\
\text { (MB/s) }\end{array}$ & $\begin{array}{c}\text { Enc. B } \\
\text { (MB/s) }\end{array}$ & $\begin{array}{c}\text { Dec. B } \\
\text { (MB/s) }\end{array}$ \\
\hline 1 & 2,70 & 3,38 & 3,16 & 4,85 \\
\hline 2 & 2,96 & 3,68 & 3,32 & 4,88 \\
\hline 3 & 3,09 & 3,51 & 3,37 & 4,40 \\
\hline 4 & 3,14 & 3,72 & 3,45 & 4,90 \\
\hline 5 & 3,15 & 3,55 & 3,75 & 4,75 \\
\hline 6 & 3,21 & 3,69 & 3,79 & 4,93 \\
\hline 7 & 3,10 & 3,66 & 3,48 & 4,96 \\
\hline 8 & 3,15 & 3,74 & 3,53 & 4,97 \\
\hline 9 & 3,15 & 3,69 & 3,88 & 4,97 \\
\hline 10 & 3,10 & 3,69 & 3,84 & 4,97 \\
\hline $\begin{array}{l}\text { Rata-Rata } \\
\text { Hitung }\end{array}$ & $\bar{X}_{A T}=\mathbf{3 , 0 7 5}$ & $\bar{Y}_{A T}=\mathbf{3 , 6 3 1}$ & $\bar{X}_{B T}=\mathbf{3 , 5 5 7}$ & $\bar{Y}_{B T}=\mathbf{4 , 8 6 2}$ \\
\hline
\end{tabular}


$\bar{X}_{A T}=$ rata-rata kecepatan enkripsi A dengan algoritma Twofish (256 bit)

$\bar{Y}_{A T}=$ rata-rata kecepatan dekripsi A dengan algoritma Twofish (256 bit)

$\bar{X}_{B T}=$ rata-rata kecepatan enkripsi B dengan algoritma Twofish (256 bit)

$\bar{Y}_{B T}=$ rata-rata kecepatan dekripsi B dengan algoritma Twofish (256 bit)

\section{Pengukuran Arus Listrik}

Hasil pengukuran arus listrik pada ponsel Samsung Galaxy Ace Duos (GT-S6802) untuk tegangan input Vi = 3,72 Volt :

Tabel 3.

Pengukuran arus Listrik

\begin{tabular}{|l|c|}
\hline \multicolumn{1}{|c|}{ Keadaan } & Arus (A) \\
\hline Start up & $0,04-0,32$ \\
\hline Idle & 0,06 \\
\hline Enkripsi /Dekripsi & 0,24 \\
\hline
\end{tabular}

Analisis Kecepatan dan Waktu Enkripsi/Dekripsi AES (256 bit) dan Twofish (256 bit)

Berdasarkan Tabel 1 rata-rata kecepatan enkripsi algoritma AES (256 bit) adalah 2,65 MB/s untuk data yang berukuran 15.360 byte (Enkripsi A), rata-rata kecepatan untuk mengenkripsi data berukuran 262.144 byte (Enkripsi B) adalah 2,94 MB/s, ratarata kecepatan dekripsi A adalah 2,654 MB/s, dan dekripsi B adalah 3,462 MB/s. Sedangkan untuk algoritma Twofish (256 bit) rata-rata kecepatan enkripsi $\mathrm{A}=3,075$ $\mathrm{MB} / \mathrm{s}$, enkripsi $\mathrm{B}=3,557 \mathrm{MB} / \mathrm{s}$, enkripsi $\mathrm{A}=3,631 \mathrm{MB} / \mathrm{s}$, dan dekripsi $\mathrm{B}=4,858 \mathrm{MB} / \mathrm{s}$ (Tabel 2).

Untuk memudahkan dalam perhitungan maka kecepatan enkripsi/dekripsi diasumsikan sebagai rata-rata dari enkripsi/dekripsi A dan B, dengan demikian untuk algoritma AES:

- Kecepatan enkripsi:

$$
v_{e n k A E S}=\frac{\bar{X}_{A A}+\bar{X}_{B A}}{2}=\frac{2,650 \mathrm{MB} / \mathrm{s}+2,940 \mathrm{MB} / \mathrm{s}}{2}=2,795 \mathrm{MB} / \mathrm{s}
$$

- Kecepatan dekripsi:

$$
v_{d e k A E S}=\frac{\bar{Y}_{A A}+\bar{Y}_{B A}}{2}=\frac{2,654 \mathrm{MB} / \mathrm{s}+3,462 \mathrm{MB} / \mathrm{s}}{2}=3,058 \mathrm{MB} / \mathrm{s}
$$

untuk algoritma Twofish:

- Kecepatan enkripsi:

$$
v_{e_{n k T \text { wofish }}}=\frac{\bar{X}_{A T}+\bar{X}_{B T}}{2}=\frac{3,075 \mathrm{MB} / \mathrm{s}+3,557 \mathrm{MB} / \mathrm{s}}{2}=3,316 \mathrm{MB} / \mathrm{s}
$$


- Kecepatan dekripsi:

$$
v_{\text {dek Twofish }}=\frac{\bar{Y}_{A T}+\bar{Y}_{B T}}{2}=\frac{3,631 \mathrm{MB} / \mathrm{s}+4,858 \mathrm{MB} / \mathrm{s}}{2}=4,244 \mathrm{MB} / \mathrm{s}
$$

Waktu yang dibutuhkan untuk enkripsi/dekripsi pesan dapat dihitung dengan membagi ukuran pesan dengan kecepatan enkripsi/dekripsi. Misalnya waktu yang diperlukan oleh algoritma AES untuk mengenkripsi pesan yang berukuran 15,360 KB adalah :

$t_{\text {enkripsi }}=\frac{\text { ukuran pesan }}{\text { kecepa } \tan \text { enkripsi }}=\frac{15,36 \mathrm{~KB}}{2,795 \mathrm{MB} / \mathrm{s}}=5,496 \mathrm{~ms}$

Sedangkan waktu dekripsi adalah :

$t_{\text {dekripsi }}=\frac{\text { ukuran pesan }}{\text { kecepa } \tan \text { dekripsi }}=\frac{15,36 \mathrm{~KB}}{3,058 \mathrm{MB} / \mathrm{s}}=5,023 \mathrm{~ms}$

Dengan cara yang sama, diperoleh waktu enkripsi/dekripsi untuk beberapa ukuran pesan seperti pada tabel di bawah:

Tabel 4.

Waktu enkripsi/dekripsi beberapa ukuran pesan

\begin{tabular}{|c|c|c|c|c|}
\hline \multirow{2}{*}{$\begin{array}{c}\text { Ukuran } \\
\text { Pesan (Byte) }\end{array}$} & \multicolumn{2}{|c|}{ Algoritma AES (256 bit) } & \multicolumn{2}{c|}{ Algroritma Twofish (256 bit) } \\
\cline { 2 - 5 } & $\mathrm{t}_{\text {enkripsi (ms) }}$ & $\mathrm{t}_{\text {dekripsi (ms) }}$ & $\mathrm{t}_{\text {enkripsi (ms) }}$ & $\mathrm{t}_{\text {dekripsi (ms) }}$ \\
\hline 10 & 0.00358 & 0.00327 & 0,00302 & 0.00235 \\
\hline 50 & 0.01789 & 0.01635 & 0.01501 & 0.01178 \\
\hline 128 & 0.04580 & 0.04186 & 0.03860 & 0.03016 \\
\hline 256 & 0.09159 & 0.08371 & 0.07720 & 0.06032 \\
\hline 400 & 0.14311 & 0.13080 & 0.12063 & 0.09425 \\
\hline 512 & 0.18318 & 0.16743 & 0.15440 & 0.12064 \\
\hline 1024 & 0.36637 & 0.33486 & 0.30881 & 0.24128 \\
\hline 2048 & 0.73274 & 0.66972 & 0.61761 & 0.48256 \\
\hline
\end{tabular}

Berdasarkan Tabel 4 dapat digambarkan grafik hubungan ukuran pesan dengan waktu enkripsi, ukuran pesan vs waktu dekripsi, waktu enkripsi vs dekripsi algoritma AES (256 bit) dan algoritma Twofish (256 bit). 


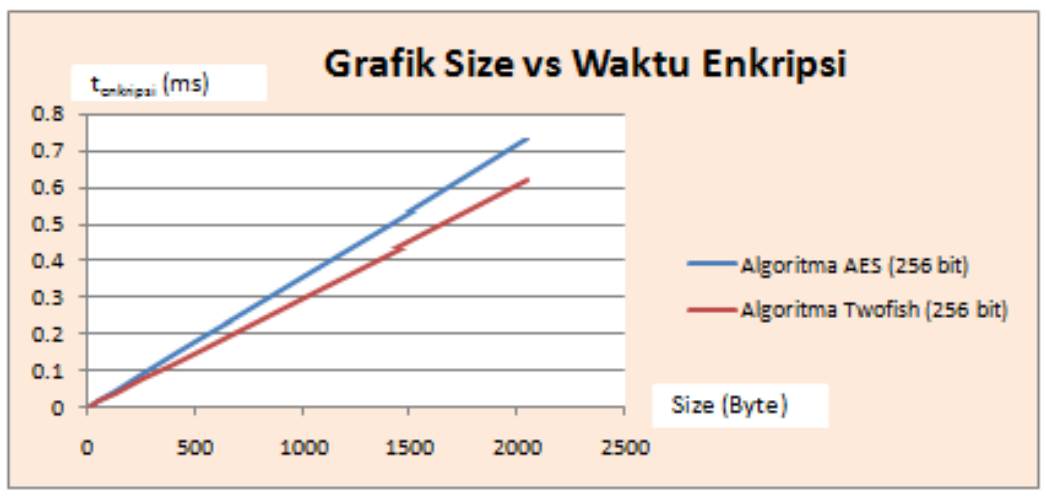

Gambar 12 Grafik size vs waktu enkripsi

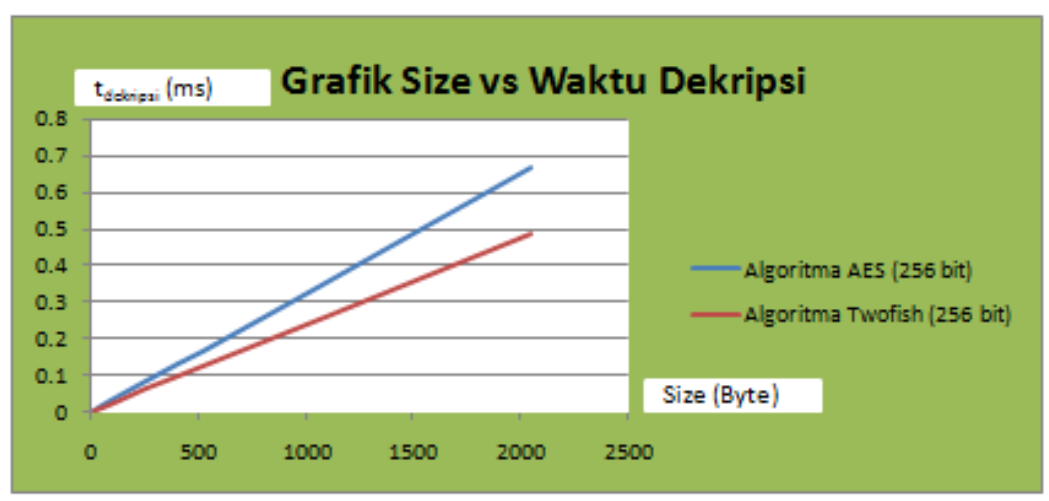

Gambar 13 Grafik size vs waktu dekripsi



Gambar 14 Grafik waktu enkripsi vs dekripsi AES (256 bit) 


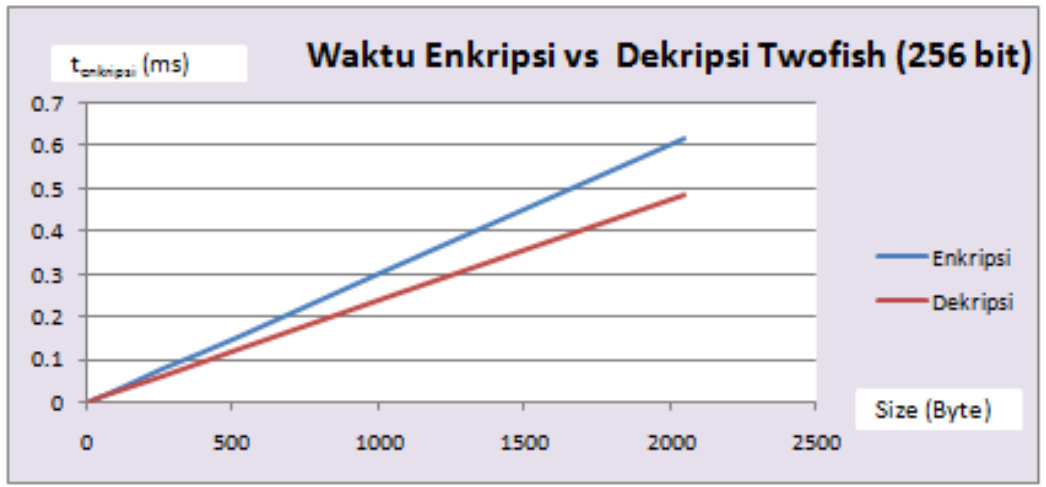

Gambar 15 Grafik waktu enkripsi vs dekripsi Twofish (256 bit)

\section{Analisis Konsumsi Energi Baterai Algoritma AES (256 bit) dan Twofish (256 bit)}

Untuk menentukan konsumsi energi dari algoritma AES (256 bit) dan twofish (256 bit) maka digunakan rumus $\mathrm{E}=\mathrm{V}$. I . t. Dari Tabel 3, arus idle $=0,06 \mathrm{~A}$ sedangkan arus pada saat enkripsi/dekripsi $=0,24 \mathrm{~A}$ sehinngga arus enkripsi/dekripsi diasumsikan $=0,24 \mathrm{~A}-0,06 \mathrm{~A}=0,18 \mathrm{~A}$. Dengan demikian konsumsi energi untuk mengenkripsi plaintext "Jam 10 am di cafe melati" dapat dihitung dengan cara:

- Dengan algoritma AES (256 bit):

Dik $:$ size $=24$ karakter $=24$ Byte

Kecepatan enkripsi $=2,795 \mathrm{MB} / \mathrm{s}$

$\mathrm{I}=0,18 \mathrm{~A}$

$\mathrm{V}=3,72 \mathrm{~V}$

maka

$\mathrm{t}=24 \mathrm{Byte} / 2,795 \mathrm{MB} / \mathrm{s}=8,587 \mu \mathrm{s}$

$\mathrm{E}=$ V.I.t $=3,72 \mathrm{~V} \times 0,18 \mathrm{~A} \times 8,587 \mu \mathrm{s}=5,75 \mu \mathrm{J}$

- Dengan algoritma Twofish (256 bit):

Dik : size $=24$ karakter $=24$ Byte

Kecepatan enkripsi $=3,316 \mathrm{MB} / \mathrm{s}$

$\mathrm{I}=0,18 \mathrm{~A}$

$\mathrm{V}=3,72 \mathrm{~V}$

maka

$$
\begin{aligned}
& \mathrm{t}=24 \mathrm{Byte} / 3,316 \mathrm{MB} / \mathrm{s}=7,238 \mu \mathrm{s} \\
& \mathrm{E}=\text { V.I.t }=0,18 \mathrm{~A} \times 7,238 \mu \mathrm{s} \times 3,72 \mathrm{~V}=4,846 \mu \mathrm{J}
\end{aligned}
$$

Dengan cara yang sama, konsumsi energi untuk beberapa ukuran pesan ditunjukkan pada tabel berikut : 
Tabel 5.

Konsumsi energi algoritma AES (256 bit) dan Twofish (256) untuk beberapa ukuran pesan

\begin{tabular}{|c|c|c|c|c|}
\hline \multirow{3}{*}{$\begin{array}{c}\text { Ukuran } \\
\text { Pesan } \\
\text { (Byte) }\end{array}$} & \multicolumn{4}{|c|}{ Konsumsi energi } \\
\hline & \multicolumn{2}{|c|}{$\begin{array}{c}\text { Algoritma AES } \\
\text { (256 bit) }\end{array}$} & \multicolumn{2}{|c|}{$\begin{array}{l}\text { Algoritma Twofish } \\
\text { (256 bit) }\end{array}$} \\
\hline & $\mathbf{E}_{\text {enkripsi }(\mu \mathrm{J})}$ & $\mathbf{E}_{\text {dekripsi }(\mu \mathrm{J})}$ & $\mathbf{E}_{\text {enkripsi }(\mu \mathrm{J})}$ & $\mathbf{E}_{\text {dekripsi }(\mu J)}$ \\
\hline 10 & 2,396 & 2,190 & 2,019 & 1,578 \\
\hline 50 & 11,979 & 10,948 & 10,097 & 7,889 \\
\hline 128 & 30,665 & 28,028 & 25,847 & 20,195 \\
\hline 256 & 61,330 & 56,055 & 51.694 & 40,391 \\
\hline 400 & 95,828 & 87,587 & 80,772 & 63,110 \\
\hline 512 & 122,660 & 112,111 & 103,388 & 80,781 \\
\hline 1024 & 245,320 & 224,222 & 206,776 & 161,562 \\
\hline 2048 & 490,641 & 448,444 & 413,553 & 323,125 \\
\hline
\end{tabular}

Berdasarkan Tabel 5 dibuat grafik hubungan konsumsi energi dengan algoritma enkripsi dan konsumsi energi vs algoritma dekripsi.

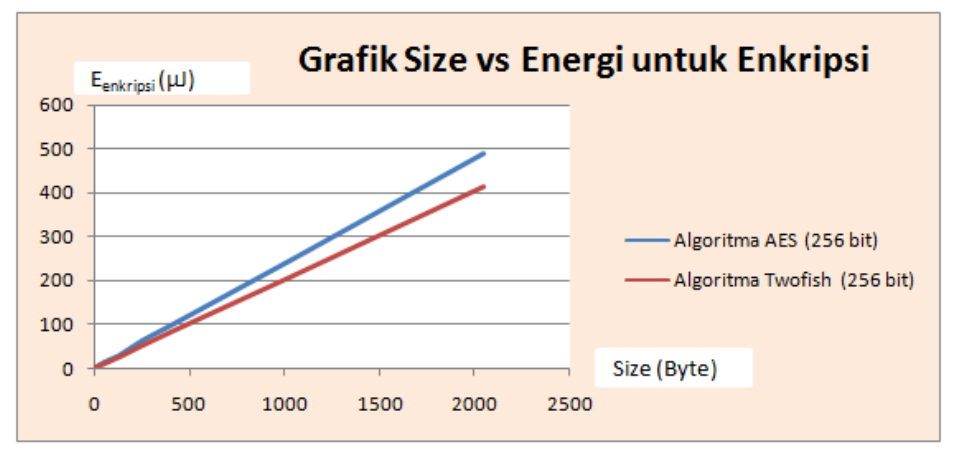

Gambar 16 Grafik konsumsi energi vs algoritma enkripsi

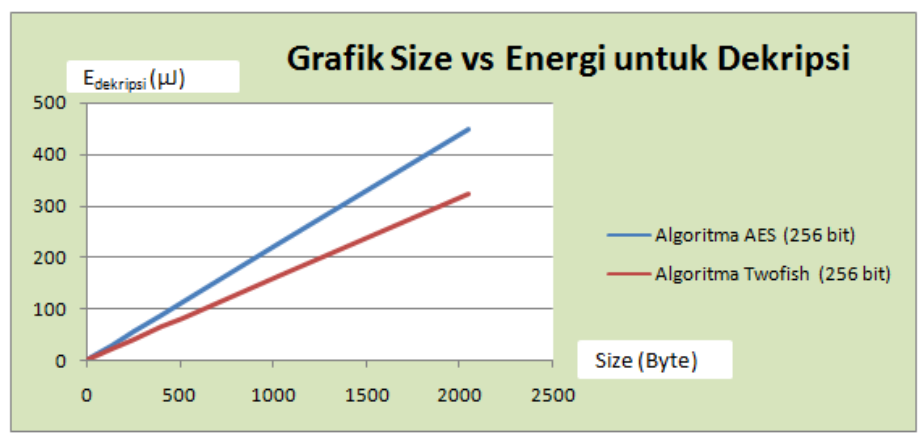

Gambar 17. Grafik konsumsi energi vs algoritma dekripsi 
Dari gambar di atas terlihat bahwa energi yang digunakan untuk enkripsi/denkripsi AES (256 bit) lebih besar daripada energi enkripsi/dekripsi Twofish (256 bit). Untuk tegangan (V) dan arus (I) tetap maka perubahan energi bergantung pada waktu enkripsi/dekripsi (t), karena t adalah ukuran pesan (z) dibagi kecepatan enkripsi/dekripsi $(v)$ sedangkan kecepatan enkripsi/dekripsi diasumsikan konstan maka perubahan energi akan berubah secara linier terhadap perubahan ukuran pesan (z). Dengan demikian dapat dibuat persamaan linier untuk energi enkripsi/dekripsi sebagai berikut :

$\mathrm{E}=\mathrm{mz}$

dengan $m=\frac{V . I}{v}$

Berdasarkan persamaan (2) dan (3) maka dapat dibuat persamaan linier untuk energi enkripsi/dekripsi sebagai berikut:

a. $\operatorname{AES}(256$ bit)

- Energi enkripsi

$$
E=m z=\frac{V . I}{v} z=\frac{3,72 V x 0,18 A}{2,795 M B / s} z=0,24 z \quad(\mu J)
$$

- Energi dekripsi

$$
E=m z=\frac{V . I}{v} z=\frac{3,72 V x 0,18 A}{3,058 M B / s} z=0,22 z \quad(\mu J)
$$

b. Twofish (256 bit)

- Energi enkripsi

$$
E=\frac{3,72 V x 0,18 A}{3,316 M B / s} z=0,20 z \quad(\mu J)
$$

- Energi dekripsi

$$
E=\frac{3,72 V x 0,18 A}{4,244 M B / s} z=0,16 z \quad(\mu J)
$$

\section{KESIMPULAN DAN SARAN}

Energi enkripsi algoritma AES (256 bit) dan Twofish (256 bit) pada ponsel Samsung Galaxy Ace Duos (GT-S6802) berubah secara linier terhadap perubahan ukuran pesan menurut persamaan $\mathrm{E}=0.24 \mathrm{z}$ untuk algoritma AES (256 bit) dan $\mathrm{E}=$ $0.20 \mathrm{z}$ untuk algoritma Twofish (256 bit). Dengan demikian energi enkripsi Twofish (256 bit) adalah 83,33 \% dari energi AES (256 bit) atau lebih kecil 16,67\% dari algoritma AES (256 bit).

Energi dekripsi algoritma AES (256 bit) dan Twofish (256 bit) berubah secara linier terhadap perubahan ukuran pesan menurut persamaan $\mathrm{E}=0.22 \mathrm{z}$ untuk algoritma AES (256 bit) dan $\mathrm{E}=0.16 \mathrm{z}$ untuk algoritma Twofish (256 bit). Dengan demikian energi dekripsi Twofish (256 bit) adalah 72,72\% dari energi AES (256 bit) atau lebih kecil 27,27 \% dari algoritma AES (256 bit). 
Penelitin ini hanya membandingkan AES (256 bit) dan Twofish (256 bit) dari segi konsumsi energi untuk peneliti yang berikut disarankan membandingkan keamanan algoritma AES (256 bit) dan Twofish (256 bit) pada ponsel berbasis android.

\section{DAFTAR PUSTAKA}

Chandramouli, R., Bapatla, S., Subbalakshmi, K.P. 2006. "Battery Power-aware Encryption." ACM Transactions on Information and System Security (TISSEC). Vol. 9, No. 2. New York, USA

Khatri,N., Dhanda, R., and Singh, J. 2012. "Comparison of Power Consumption and Strict Avalanche Criteria at Encryption/Decryption Side of Different AES Standards." IJCER. Vol. 2, No.4.

Minaam, D. S. A., Abdual-Kader, H. M., and Mohiy. 2010. "Evaluating the Effects of Symmetric Cryptography Algorithms on Power Consumption for Different Data Types.” IJNS, Vol. 11.

Potlapally, N.R, Ravi S.R.A, Jha N.K. 2003. "Analyzing the Energy Consumption of Security Protocols." Prosiding International Symposium on Low Power Electronics and Design. Seoul, South Korea.

Sinha, A and Chandrakasan, A. P. 2001. "Joule Track-A Web Based Tool for Software Energy Profiling." Proceedings of the 38th Design Automation Conference. DAC Las Vegas, USA. 